\title{
Testing the Effectiveness of 7E-Inquiry Integrated Module on Learning Achievement of Form Two Basic Science Students with Different Cognitive Level
}

\author{
Ibrahim Alahassan Libata ${ }^{1,2, *}$, Mohd Norawi Ali $^{1}$, Hairul Nizam Ismail ${ }^{1}$ \\ ${ }^{1}$ School of Educational Studies, Universiti Sains Malaysia, Pilau Penang, Malaysia \\ ${ }^{2}$ Department of Science Education, University of Science and Technology, Aliero, Nigeria
}

Received November 11, 2020; Revised January 11, 2020; Accepted January 28, 2021

\section{Cite This Paper in the following Citation Styles}

(a): [1] Ibrahim Alahassan Libata, Mohd Norawi Ali, Hairul Nizam Ismail , "Testing the Effectiveness of 7E-Inquiry Integrated Module on Learning Achievement of Form Two Basic Science Students with Different Cognitive Level," Universal Journal of Educational Research, Vol. 9, No. 2, pp. 398 - 411, 2021. DOI: 10.13189/ujer.2021.090216.

(b): Ibrahim Alahassan Libata, Mohd Norawi Ali, Hairul Nizam Ismail (2021). Testing the Effectiveness of 7E-Inquiry Integrated Module on Learning Achievement of Form Two Basic Science Students with Different Cognitive Level. Universal Journal of Educational Research, 9(2), 398 - 411. DOI: 10.13189/ujer.2021.090216.

Copyright@2021 by authors, all rights reserved. Authors agree that this article remains permanently open access under the terms of the Creative Commons Attribution License 4.0 International License

\begin{abstract}
The purpose of this study is to investigate the effectiveness of $7 \mathrm{E}$ Inquiry Integrated Module. The purposive sampling method was used to select 73 participants distributed among Concrete, and formal cognitive levels based on (LCTSR) Lawson Classroom Test of Scientific Reasoning. States of Matter Achievement Test (SMAT) was used in pre-test and Posttest and delayed posttest for data on academic achievement. The researchers randomly assigned students to an experimental group (39 students) and a control group (34 students). Four research questions guided the study. Meanwhile, the standard deviation was used to answer the research questions. The Mixed between and within-subject ANOVA and Kruskal-Wallis tests and Mann-Whitney test were used to test the Null Hypotheses at $\mathrm{P}<0.05$. The significant findings revealed that the experimental group students evidenced more learning achievements and retention of information than the control group students $(p<0.05)$. The Formal developmental level students showed more learning achievements than the Concrete developmental level students $(p<0.05)$ across the group. Statistical interactions of phase and treatment were found to be significant $(\mathrm{p}<0.05)$ in learning achievement.
\end{abstract}

Keywords 7E-Inquiry Integrated Module, States of Matter, Academic Achievement, Cognitive Level

\section{Introduction}

The primary objectives of the United Nations' Sustainable Development Goals (UNSDGs) are to eliminate poverty, protect the planet and ensure prosperity for all by the year 2030 [1]. These objectives can only be actualized by tremendous efforts in the development of education, especially science education. The world today faces crisis on quality learning. However, controversy has continued to emerge as how best is to teach students in this $21^{\text {st }}$ century, more especially students on different cognitive architectures [2]. Nigeria as a country faced the same challenges considering several efforts made by the federal government and key stakeholders to make sure the overall goal of its education is achieved. Unfortunately, not much has been achieved, as the efforts yielded only minimal result as the case of students' bad performances persist [3]. According to Ayodele [4] in the face of great significance attached to science education in the society, there has been reported students' low level of achievement at all levels of education in schools, as revealed in public examinations results. This is evident from the recent examiners reports of the junior secondary school living certificate examination with lower percentages of passes over the years: $36.6 \%$ in 2013, 33\% in 2014, 38\% in 2015, $20.1 \%$ in 2016 and $39 \%$ in 2017 [5]. These low achievements according to Samuel [6] are as result of the teaching strategy employed by the basic science teachers. 
On the other hand, Idowu (2011) argued that the problems steam from students lacking good background in basic science which is a prerequisite for studying science discipline (chemistry, biology, physics) in tertiary institution.

States of matter is one of the key topics in basic science and a background for further studies in biology, chemistry, and physics. Students' misconception about states matter has been generally reported as one major obstacle to students' understanding about subject matter. The types of information which contradict scientific claims are defined in various ways as misconceptions, alternate frameworks, intuitive beliefs, perceptions of ideas, spontaneous thought, child science and naive beliefs [7]. The results of the earlier quantitative and qualitative research on the understanding of the matter concepts and its changes of states showed that majority of children do not master the concepts and have different misconceptions about the transformation of changes in states of matter [8]. There is a misconception on the properties of matter, students believe "since ice is solid then its molecules are solid and since water is liquid also its molecules are liquid" [9]. It has been reported that students generally have trouble in conceptualizing a gas to be a substance, with many believing that a gas is weightless or is lighter than solids and liquids [10-13]. Consequently, the current practice of teaching and learning in the classroom is doing more harm than good on misconceptions students has on transformations of states of matter. This is evident from several research reports indicating students being taught under teacher centre method [14-17]. It is believed that identifying and redefining the prior conception of students using appropriate teaching strategies is imperative for student's success [18]. The elicit stage of the 7E-IIM allows teacher to identify the prior information of students which helps the teacher to choose further information to be learn by the students.

\section{Students Misconception on State of Matter: An Overview}

For decades, a considerable amount of research was undertaken that shed light on the students' learning about the structure of matter and its changes of states [19-25]. All related studies have documented difficulties and misconceptions in this field. States of the matter is one of the key topics under basic science and background for further studies in biology, chemistry, and physics. Students' misconception about states matter has been generally reported as one major obstacle to students' understanding of the state of matter. The findings of quantitative and qualitative research into the learning of concepts of matter and its changes of states demonstrated that most children do not master the concepts and have different misconceptions about the transformation of changes in states of matter [8]. The author added that students were confused between the concepts of "shape, size and weight" of solid, liquid and gas. It was reported that students generally have trouble in conceptualising a gas to be a substance, with many believing that gas is weightless or is lighter than solids and liquids [10-13]. It is believed that misconceptions affect students' way of interpreting and constructing new concepts [26]. The report also maintains that misconceptions may originate from particles drawings related to solids, liquids, and gases in the texts. Because solids molecules have been packed together and usually are seen in a regular pattern in pictures. According to the participants, since the particles of solids are more significant in comparison to others, they seem entrapped in comparison to liquids and gases with the same volume. Since the gaps between solid particles are small, the particles cannot take any substances between themselves and move in any way [8, 27].

Cantu and Herron [28] argue that students do not spontaneously acquire a general idea of gas before their formal introduction to the concept. The author articulates that students later show evidence of the inherent difficulty in conceiving the structure of a gas state. Similarly, results have shown that students also hold alternative conception regarding the bubbles that rise from boiling water [13, 29]. An additional and exciting point is that students have a great deal of difficulty understanding that the properties of the states of matter are due to the collective behaviour of particles [30]. They often regard a particle or a molecule as a little quantity of a substance having all the macroscopic properties of the substance [31, 32]. That is, ice molecules or particles are regarded as frozen or solid molecules," water molecules as liquid molecules, and so forth [22]. Furthermore, many students were not able to think; clearly, students jumbled observable substance properties with molecular properties, attributing changes in substance to changes to the molecules [22].

Significant conceptual difficulties are reflected in the way that students make a distinction in states of matter transformation. Nguru [8] reports that students' misconceptions about liquids are because liquids are simply known to be in an intermediate state between solids and gases. In this context, the molecular spacing of liquids is overestimated. Likewise, several students have assumed that particles in the gas and liquid state are in continuous movement, there is no movement of particles in the solid-state [11, 13]. In another report, molecular gases spacing was underestimated and students ignored the movement of particles [33]. There have also been cases of misperceptions regarding particles size. The most common misconception of students is that gas is neither a material nor has weight or mass $[12,13]$.

In an attempt to further investigate the various difficulties students faces, a longitudinal study with secondary pupils aimed at further exploring different perceptions of the nature of matter, a longitudinal study with secondary English pupils (age 11-14) was carried out 
by Tsitsipis, Stamovlasis [30]. Students' understanding of the structure of matter and its changes of state, such as melting, evaporation, boiling, and condensation was also investigated in relation to three cognitive variables: logical thinking (LTh), field dependence/independence, and convergence/divergence. The study aims to explore the effectiveness of context-based instruction integrated with learning cycle model as compared to the traditional instruction on tenth-grade students' achievement and knowledge retention on the states of matter subject and their attitudes toward chemistry. A total of 150 tenth grade students of two high schools were the participants of the study. During the treatment, experimental group students received context-based instruction integrated with the learning cycle model, whereas control group students received traditional instruction. The treatment lasted for six weeks, and the data were collected through the "States of Matter Achievement Test" and "Affective Characteristics Questionnaire". The result of MANCOVA revealed that the context-based instruction integrated with learning cycle model resulted with significantly higher achievement scores and higher knowledge retention on the states of matter subject and better attitudes towards chemistry when compared to the traditional instruction. The study took place in Greece with the participation of 329 ninth-grade junior high school pupils (age 14-15). The results showed that students had difficulty in conceiving the notion of "space" between particles.

As a consequence, they reacted inappropriately by filling space between gas particles with other particles, such as air or dust. To contribute to further clarification of students' particle ideas and to facilitate their better understanding regarding the changes of state, Sunar [27] applied thoroughly quasi-experimental design in a teaching intervention and compared the results to those of a corresponding intervention without the use of the software. In both, control and experimental interventions, the concepts of the particle theory of matter were implemented. The writers collaborated with 52 university students enrolled in introductory chemistry courses. The findings showed that the teaching approach followed was a successful way to minimise the number of alternative conceptions that students held about the boiling term" (p. 531). However, "Some students have retained their alternate conceptions during the study." (p. 532), for example. In contrast, students believe that bubbles in boiling water contain air decreased from pre-test (27\%) to post-test (23\%) (p. 533), the belief finally increased considerably (47\%) in a retention post-test.

In all accounts, the results of teaching approaches reinforce the proof that, despite the improvements may be made by effective teaching techniques, the students' misconceptions about particles and the physical changes in the matter seem to continue to a significant degree. The question still raised is what hinders the comprehension of the students? Especially the partially effective teaching recorded in the literature and the fact that many students are able to approach the science view, while many others are far behind, suggest that the individual differences that researchers overlooked in the related research might be worth investigating. In the light of the above reported findings, the present study seeks to contribute to the existing knowledge the influence of the constructivist approach to the matter and its changes of states instruction.

To achieve effective learning in science, a student's misconception must be eradicated from an individual. In this context, the role of the teachers in selecting effective and most relevant pedagogy is imperative. It is crucial to adopt an instructional approach that reduces students' misconceptions and subsequently improves students' learning of science, and the present study adapted the 7Es learning approach. Accordingly, several empirical studies have established and demonstrated the potentials of the 7Es learning cycle and its effect on the quality and use on individual learning by inquiry [34-46]. The 7E learning cycle is a procedure structured by and for teachers that looks to expand the effect of instruction investigation into improved practice [47].

However, controversy has continued to emerge as to how best it is to teach students in this $21^{\text {st }}$ century, more especially students on different cognitive architectures [2]. Over the years, research in science education aimed at arresting the low academic achievement of students in Nigeria have been conducted [4-6, 14, 17, 48-59]. Though these studies have been reported and cited as solutions to the lingering low academic achievement of students, they may not fully realise the goals of improved students learning of matter and its changes of states. There is a strong belief that no two students in the class understand the same way in each lesson or any given activity due to individual differences [60]. Consequently, the current practice of teaching and learning in the classroom is doing more harm than good on misconceptions students have on transformations of states of matter. This is evident from several research reports indicating students being taught under teacher centre method [14-17].

In view of all that has been mentioned about students' challenges in the understanding matter and its changes of state, the present study will not attempt to add many difficulties to students but will rather focus more on instructional approaches that are found to improve students' achievement with the aim to end the lingering students' misconception which invariably results in low achievement. Although research on constructivist instruction has been conducted and reported on the efficacy the 7E model on student learning [34, 46, 61-64] as earlier attest, little or none of this study investigated the efficacy of $7 \mathrm{E}$ on Piaget's cognitive level as a predictor of student learning of matter and its changes of states. Moreover, the reviewed literature are mostly studies dealing with the higher-level students. In the same vein, none has substantially reported empirical data that directly relate the variables under this 
study. The reviewed studies demonstrated only the variables classified under students' achievement, attitude, motivation, critical thinking, retention, gender, and age.

Drawing on the aforementioned, it is evident that there is little research effort around the influence of the 7Es learning cycle in the teaching of matter and its changes of states among students of different cognitive abilities, more specifically in northern Nigerian Junior Secondary Schools. A few related studies to this topic include the works of [35, 42, 43]. These studies were conducted in the senior secondary school setting. However, none of the works reviewed above was conducted among students of different cognitive abilities within the junior secondary school setting in Nigeria. Based on the previous studies, the researchers have convinced no empirical studies with $7 \mathrm{E}$ model have been conducted on students with different cognitive abilities in States of matter achievement and retention, hence the justification for performing the present research. Since the efficacy of the 7E model on these students of different cognitive abilities is yet to be established, this study therefore set out to assess the effect of $7 \mathrm{E}$ learning cycle. The present study will go a step further to contribute to the existing knowledge in providing more details on the effect of the 7Es learning cycle model on concrete and formal students' academic achievement to see if there is a significant mean difference between concrete, and formal students taught through 7E-IIM in terms of achievements.

Those students who expose to mind on activities of learning science are believed to attain success in science class [65]. It is globally accepted that learning of science is a continuous construction and reconstruction of information [65]. Moreno [66] reported that there is an increasing body of research suggesting that students learn more deeply when they are strongly guided. The 7E-IIM was developed to provide a full guided sequence of instruction that one should go through in solving a problem; it contains some hints and evaluation phase aim to facilitate the teaching of science. According to Kirschner, Sweller [2], the instructional sequence that failed to acknowledge the structure that constitutes human cognitive architecture is likely to be ineffective. Cakici and Yavuz [67] and Yilmaz [68] claim that instruction not within the cognitive development of the learner demolished their confidence and enthusiasm towards science class, which consequently result to poor learning. The 7E-IIM was designed to identify and support students with different cognitive abilities. The aim of all instruction is to bring a positive change to the learner. It was reported that teachers who achieved many of their goals due spend time on instructional interaction with their student by continuously teaching relevant subject matter [69]. To achieve the aim of this study, the sequentially 7E-IIM was flexible to adapt to different learning situations for teachers and students to share ideas and skills.

There is a strong belief that the student who lacks proper
Schemas to integrate the new information with their prior knowledge finds it very complex to learn [2]. This suggests that there is a need for an instructional approach that takes into cognizance the individual differences in the learning situation. The elicit phase in the 7E-IIM provides the teacher to elicit the learner's prior knowledge that will consequently determine further information to learn. In every science class, students bring in conflicting ideas or information from their everyday life. These contradictory ideas can only be demonstrated in a view to turning personal beliefs to a proper science knowledge in a guided science class [65].

According to Oluremi and Oyewole [70], there is continuous complaint about the low performance of children, failure rate, high dropout rate and poor reading and writing skills among students at all levels. Odia and Omofonmwan [14] concede that low performance is related to the type of instructional approach science teachers adapted. Studies have reported shreds of evidence which show students underachievement in Basic Science at the Junior Secondary School level [4, 49, 54, 57]. It is widely acknowledged that students often struggle with abstract concepts in the learning process, yet the pedagogy employed in most science classrooms does not address the students' needs to develop appropriate mental models of abstract science concept [15, 16, 71].

Most of the science concepts are abstract in nature. The correct classification of these concepts cannot be centred on identification or direct observation, either because these concepts lack identifiable examples, or the crucial concepts are not observable in the examples [28]. For example, if one wants to teach the concept of the ideal gas, it is difficult to establish to the students that particles of ideal gas do not occupy any space and exert no force on each other by pointing to these attributes in examples of the ideal gas. Ideal gasses do not exist. Cantu and Herron [28] further insist that, even if there are examples, we could not use examples to show these attributes of the concept, because our senses are unable to identify atomic particles. An ideal gas is abstract because there are no measurable examples, and the attributes are not perceptible. Comprehending abstract concepts requires more than carrying out logical operations on a concrete reality. In view of the number of abstract concepts faced in science, the learning difficulties inherent in these concepts, and the number of science students working at a concrete-operational level, it is imperative to adopt a strategy that ensures both concrete and formal students learning.

\section{Eisenkraft's Learning Cycle (The 7E Model)}

Most of the research on the effectiveness of the 7Es model has been conducted in Turkey, where a constructivist approach to science curriculum development 
and science education was adopted in 2005 [72]. The present study thus adds to the picture by considering the 7Es Model inquiry in Nigeria. Learning cycle is an inquiry learning instruction for learners to investigate the scientific knowledge using science process skill to acquire knowledge or significant self-learning information based on constructivist theory [73]. The previous learning cycle comprises three steps: surveying, introducing keyword/building concept for achieving concept, and applying the concept. The learning cycle, then, has been adapted into four steps called the 4E learning cycle approach by adding the step of learning presentation. Later, the $4 \mathrm{E}$ learning cycle approach has been adapted into the $5 \mathrm{E}$ by adding the step of prior knowledge check. Finally, it was extended from the $5 \mathrm{E}$ to the $7 \mathrm{E}$ learning cycle by including the steps of examining prior knowledge and applying knowledge [47]. Consequently, the 7Es learning cycle emphasizes examining the learner's prior knowledge for what they want to know first before learning the new content. The sequence of the $7 \mathrm{E}$ learning cycle support effective learning process through seven steps: examining prior knowledge, motivating interests, surveying, and searching, explaining, extending knowledge, evaluating, and applying knowledge [73]. Based on research into curriculum and lesson plans, Eisenkraft [47] expanded the 5E model to a 7Es model that stresses knowledge transfer [74]. The newer model adds an "elicit" stage before "engage" and an "extend" stage after "evaluate" and the effort has been endorsed by Bybee [74].

The pattern of the learning cycle is an inquiry by nature for learners to investigate the scientific knowledge through science process skills to search for knowledge or significant self-learning experience based on constructivist theory under the guidance of a facilitator. Learning is defined as a very personal and adapted experience for students who usually must follow an educator's pedagogy or strategy of teaching [75]. Several versions of the learning cycle appear in the science curriculum, with phases ranging from three to five to seven. Irrespective of the number of phases, each learning cycle has the same objective at its core, which is to provide a level playing field for a person to explore information. The learning cycle used in this study is the [47] learning cycle, which has seven phases (7Es learning cycle). The expended version of the $5 \mathrm{E}$ learning cycle ensures developing prior knowledge at the beginning and the transfer of experience at the end of the instruction.

Studies have shown that learning cycle model has a positive impact on some teaching contents and is an effective tool for teaching concepts. It also has a positive impact on students' achievement, can increase students' awareness overtime, allow students to build or enhance positive attitudes towards courses and provide students with science, experimental and practical thought [36, 40, 46, 47, 72, 76-81]. Application of the 7Es learning cycle in science learning increases students' success and conceptual achievement more efficiently because the model has been prepared to give students the chance to explore ideas. However, the fact that the phases of the model are teacher/student-friendly, effective learning takes place. Though the 7Es learning cycle can be time-consuming because each phase should be carried out with great attention to details, it is found that the learning cycle provides a greater opportunity for the acquisition of scientific conceptions than the traditional methods [41].

An inquiry is an instructional approach that follows the constructivist view on how students learn. The learning cycle is an inquiry-based instructional approach or model with its roots on the constructivist perspective [82, 83]. Constructivism theory forms the basis for inquiry-based learning, which focuses mainly on the works of Piaget and Vygotsky. Several researchers have agreed that there is a high ranking of inquiry activities ranging from teacher-centred to student-centred [84, 85]. Constructivists believe that meaningful learning occurs if students are actively involved in their learning activities by being authentically engaged in the problem-solving process [42, 64]. Quality teaching is better when teachers ask questions and students discover for themselves and answer the question, rather than transmitting the knowledge, an inquiry is when students are involved, ask a question, reflect, and identify the problem, then typical classroom situations where teachers just pass information to students. Learning cycle approach is inquiry-based learning and it is "goal is to enhance learning and provide students with more authentic science experience that imitate those real scientists and are in accordance with the nature of science" [80].

According to Celik, Özbek [38] in utilizing the learning cycle, students can learn science concepts, fix their erroneous or inadequate information. They further affirm that students can significantly become familiar with the ideas, and adapt the learning gained in school to their everyday life. A similar finding was reported by [78, 86]. Also, Gürbüz [87] studied the effect of 7Es instructional model on academic achievement and retention of knowledge in the unit of "Electricity in our Life" in 6th-grade science and technology, using materials which were developed in accordance with 7Es learning model in a science lesson at secondary school. The findings of the study indicate that the materials prepared in accordance with the 7Es learning model enhance students' academic excellence and increase the permanency of knowledge.

To review the first stage of the 7Es model (elicit), Eisenkraft [47] distinguished this stage from "engage" to draw attention to the importance of accessing students' prior knowledge since they use it to construct new knowledge. One simple way in which a teacher may encourage students' participation in this stage is to ask for their thoughts or beliefs about a topic. Thus, in State of Matter class, a teacher may pose a question to the class, designed to elicit students' prior knowledge. Basic science 
teachers can also assess students' misconceptions about a topic during the elicit stage. The elicit stage is closely followed by the engage stage, the main goal of which, in either the 5Es or 7Es model, is to capture the students' attention [47]. Teachers ask questions, pose problems, or present conflicting notions of piquing a student's interest. Students should be puzzled and thoughtful about the content during this stage, which does not have to involve a full lesson but can be merely a brief demonstration designed to spark students' interest and raise questions in their minds [74]. The "engage" and "elicit" stages are distinguished, again, to make sure that students' prior knowledge is accessed [47].

\section{Theoretical Framework}

The theoretical framework has been described as a general representation of the relationship between things in the phenomena, in other words, it means the relationship between theories and variables under study [88]. This study was underpinned by two constructivism's learning theories (Piaget cognitive constructivism and Vygotsky social constructivism). According to constructivism, learners individually construct their own knowledge [89]. The present study is to determine the effects of the 7Es inquiry Integrated Teaching Module on the achievements of form two learning of matter and its changes of states. These educational theorists have tried to describe how learning takes place in the learner, emphasizing the type of environment and cognitive development that should be considered to promote learning. The choice of these theories is born out of the fact that the relationship between theories of learning and educational practices is complicated. It is difficult for one to conclude that all learning is based on a given theory.

There is no single theory that can explain learning in all situations and in all types of learning [90]. Each of the two learning theories selected to be the theoretical base of this research has an essential ingredient that makes the designed teaching model unique and effective in addressing learning problems in the 7E-Inquiry classroom design. While the social cognitive theory views learning as an interactive process of negotiation and discussion, it stresses collaboration and information sharing in learning. The scaffolding theory maintains that individuals under the same condition come out with different knowledge. It stresses the need for teachers to support the learners in their learning tasks through scaffolding [91]. Scaffolding in this situation can be provided by the teacher or peers either in the face-to-face learning setting or using 7Es phases of learning; guidance can be provided at the beginning of each activity, and eventually be removed as the child progress on his/her own pace [92]. The 7E Inquiry Integrates Module (7E-IIM) is designed to include practical activities during class sessions.

\section{Methodology}

The study employed a pre-test, posttest, and delayed posttest quasi-experimental design. For clarity and consistency, throughout the study Phase1, Phase2 and Phase3 terms will be used to refer to pre-test, posttest, and delayed posttest on all implementations, respectively. The sample of the study consisted of 73 students of forming two Junior Secondary Schools. Purposive method of sampling was used. This was to ensure selection based on Piagetian age of formal and concrete developmental stages. The sample was administered the Lowson Classroom Test of Scientific Reasoning (2000) to classify the student into Concrete, and formal, based upon criteria discussed in Lawson (1978) as in modified 2000 [93]. State of Matter Achievement Test (SMAT) instrument was used for data collection on academic achievement on states of matter. The test was based on the unit of form two basic science and technology "Type of Energy".

(a) Lawson Classroom Test of Scientific Reasoning (LCTSR): It consisted of ten multiple-choice items. (Adopted from Revised Edition: August 2000). The object of the instrument is to test the reasoning ability of the respondents, consequently classified the respondents into Concrete, and a formal group of reasoning. The instrument was scored from 0-10. The participants who scored 0-5 and 6-10 were a group as Concrete and formal, respectively.

(b) State of Matter Achievement Test (SMAT): According to Korb [94], if the researcher(s) find no other instruments available, then the last option is to develop an instrument. This test was developed by the researchers to measure the achievement of the respondents. The test is composed of twenty-five items. The twenty-five items were drawn from the junior secondary school syllabus. The researcher was assisted by Basic Science teacher (research assistant) in administering these instructional materials. States of Matter Achievement Test was pilot tested with 30 students for the reliability, responses obtained from the pilot testing were subjected to a statistical analysis using the Kuder-Richardson (KR-21) and a coefficient $\mathrm{KR}=0.73$ was realized. According to Wells and Wollack [95], index scale of 0.70 or high is the desirable reliability coefficient.

In the first week, both experimental and control group were pre-tested with SMAT. After which treatment was followed for seven weeks of using 7E Inquiry Integrated Module. The instruction was performed for both groups with the same content for 7 weeks, 90 minutes each week, during November and January 2018/2019 calendar. The students followed the sequence of the module, which includes in and outside classrooms activities. Laboratory practical were conducted for each week of the seven weeks for the experimental group students. Similarly, participants 
were divided into groups to brainstorm and report findings on a given task. They were also engaged in some group competitions and playing games with the aim of understanding the States of matter and encouraging social interaction. Meanwhile, the control group followed textbook and teachers' explanations on the concept of matter. After the end of treatment, post-test SMAT was re-administered to both groups of students to measure their understanding of the subject matter. Three weeks later delayed Posttest followed to measure store of knowledge.

For the achievement test, the mean and deviation of each of the group at the pre-test, Posttest and delayed post-test scores were found and reported and The Mixed between and within-subjects ANOVA was used to test the Null Hypotheses at $\alpha=0.05(\mathrm{P}<0.05)$ to determine if there is any significant difference between Phase1, Phase2 and Phase3 means scores across the group. However, Kruskal-Wallis tests and Mann-Whitney test were also conducted to determine if there is any significant difference between the means score of Concrete, and formal with respect to academic achievement at Phase2. All analyses were done with the statistical package of social sciences (SPSS 20.0).

\subsection{Statement of the Problem}

According to Osuolale [17], students performed poorly in science subjects because of ineffective teaching methods, poorly equipped science laboratories and over-reliance on printed materials. Similarly, Gongden, John [96] argues that students' low performance is because of difficulties they faced in understanding science concept which include poor understanding of the particulate nature of matter. Several studies have found the learning cycle model to increase the understanding of science concepts and to address the misconceptions of students [34, 42, 46]. However, the extent to which 7E Inquiry Integrated Module (7E-IIM) predicts improved understanding of matter and its changes of states among children of the different cognitive developmental level are not clearly understood. Therefore, the purpose of this study was to investigate an instructional strategy for teaching Concrete, and Formal students learning state of matter. It is believed that good quality pedagogical instructions enable students to learn actively and motivate students' learning, thus increasing students' achievement and reducing misconceptions. The instructional strategy was a module designed around 7E learning cycle. Therefore, the present study is going to determine if there is any significant effect of 7E-IIM on concrete, and formal student's achievement.

\subsection{The Objective of the Study}

The main aim of this study is to determine whether 7E-Inquiry Integrated Module teaching is effective in the learning of form two Basic science students.

\subsection{Research Questions}

1) Is there a significant interaction between phase and treatment on students' academic achievement?

2) Is there a significant mean difference between groups exposed to 7E Inquiry Integrated Module and Conventional Method of Instruction with respect to students' Academic achievement on states of matter before the treatment (Phase1), after the Treatment (Phase2), and three weeks later the Treatment (Phase3)?

3) Is there a significant difference in the academic achievement of students at the concrete operational stage and those at the formal operational stage when exposed to 7E Inquiry Integrated Module?

4) Is there a significant difference in the academic achievement of students at the concrete operational stage and those at the formal operational stage when exposed to Conventional Method of Instruction?

\section{Result}

Data obtained using LCTSR from this study show that the sample was 56\% concrete (experimental group) and 52.94\% concrete (control group) cognitive level and 44\% formal (experimental group) and only $47.06 \%$ formal (control group) cognitive level. These results indicate that most of the sample are operating at concrete cognitive level (54.80\%) and only $45.20 \%$ constitute formal cognitive level.

(a) Ho1. There is no significant interaction between phase and treatment on students' academic achievement.

The Ho1 was investigated through Table 6.1. The Mixed Between-Within Subject ANOVA results revealed that there was a statistically significant interaction effect between phase and treatment $X^{2}=0.60, F(2,142)=15.90$, $p=0.00$. The partial $\eta^{2}$ value of interaction effect is 0.16 , indicating that $16 \%$ variance of dependent variables was explained by time and treatment effect.

Table 6.1. Mixed Between-Within Subject ANOVA Results for SMAT

\begin{tabular}{cccccc}
\hline effect & $\begin{array}{c}\text { Mauchly's } \\
\text { Test }\end{array}$ & $\begin{array}{c}\text { D } \\
\text { f }\end{array}$ & F & Sig* & $\begin{array}{c}\text { Partial } \\
\mu^{2}\end{array}$ \\
\hline Phase*Treatment & 0.60 & 2 & 15.90 & 0.00 & 0.18 \\
\hline
\end{tabular}

*Analysis was performed with the significance level of $\alpha=0.05$

The significant interaction effect means that the changes in students' SMAT scores over the phase for two groups (7E-IIM and CMI) were different. In other words, the impact of treatment (teaching method) on academic achievement of students in states of matter differs over time (see figure 6.1). Thus, the hypothesis Ho1 was rejected. 


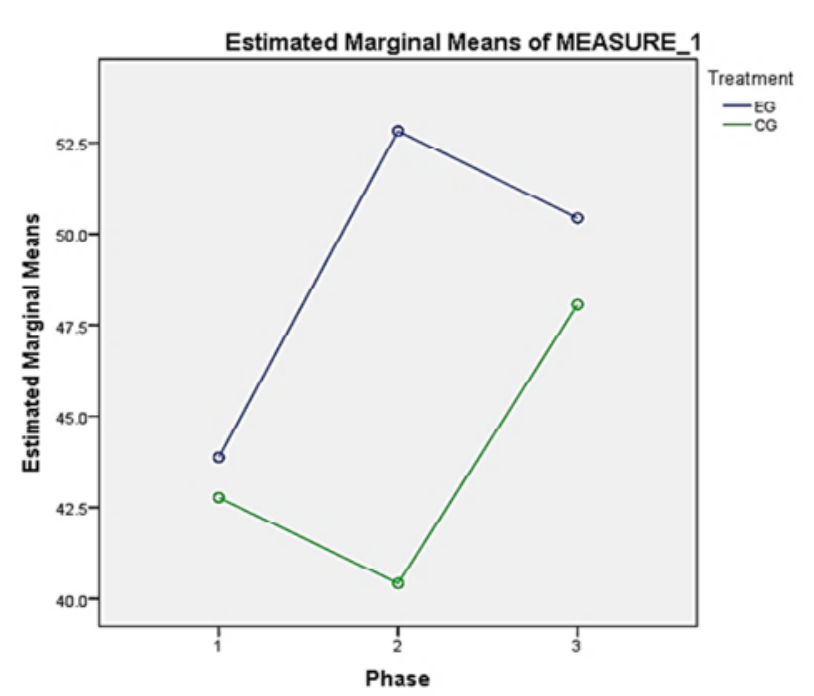

Figure 6.1. Estimated marginal means of groups

(b) Ho2. There is no significant mean difference between groups exposed to $7 E$ Inquiry Integrated Module and Conventional Method of Instruction with respect to students' Academic achievement on states of matter before the treatment (phase1), after the Treatment (Phase2), and three weeks after Treatment (Phase3)

State of Matter Achievement Test was administered before the students undergo the 7E-IIM and Posttest was administered after the completion of intervention conducted for a period of 7 weeks; however, delay post-test followed three weeks.

Table 6.2. Means of Groups with Respect to Phase for SMAT

\begin{tabular}{ccccc}
\hline Phase & Treatment & Mean & Std. Deviation & N \\
\hline \multirow{2}{*}{ Phase1 } & EG & 43.69 & 7.215 & 39 \\
& CG & 42.76 & 6.805 & 34 \\
\multirow{2}{*}{ Phase2 } & EG & 52.41 & 4.728 & 39 \\
& CG & 40.00 & 7.924 & 34 \\
\multirow{2}{*}{ Phase3 } & EG & 50.44 & 8.255 & 39 \\
& CG & 48.06 & 8.577 & 34 \\
\hline
\end{tabular}

Table 6.3. Pairwise Comparisons of Groups by Phase for SMAT

\begin{tabular}{cccccc}
\hline \multirow{2}{*}{ Phase } & \multirow{2}{*}{$\begin{array}{c}\text { (I) Treatment } \\
1\end{array}$} & $\begin{array}{c}\text { (J) } \\
\text { Treatment }\end{array}$ & $\begin{array}{c}\text { Mean } \\
\text { Difference (I-J) }\end{array}$ & $\begin{array}{c}\text { Std. } \\
\text { Error }\end{array}$ & Sig. $^{\text {b }}$ \\
\hline \multirow{2}{*}{2} & EG & CG & .928 & 1.649 & .576 \\
& CG & EG & -.928 & 1.649 & .576 \\
& EG & CG & $12.410^{*}$ & 1.505 & .000 \\
3 & CG & EG & $-12.410^{*}$ & 1.505 & .000 \\
& EG & CG & 2.377 & 1.972 & .232 \\
& CG & EG & -2.377 & 1.972 & .232 \\
\hline
\end{tabular}

As shown in Table 6.2 and Table 6.3, at the beginning of the states of matter intervention (Phase1), there was no statistically significant mean difference between the two groups regarding students' academic achievement ( $p>.05)$. At the end of the intervention (Phase2), there was a significant mean difference between the experimental group $(M=52.41)$ and control group $(M=40.00)(p<.05)$. The significant difference found between groups after the intervention aroused from the treatment effect in favor of experimental group. İn contrast, three weeks later (Phase3) no significant mean difference between the two groups was observed. This finding implied that the retention of the knowledge was not significantly different between groups $(p>.05)$. Although students in the experimental group (Phase3) slightly gain higher mean score $(M=50.44)$ than the control group students $(M=48.06)$. In other words, students exposed to 7E-IIM stored the knowledge better than students under CMI even though, it is not statistically significance.

Consequently, it can be concluded that the 7E-IIM experience as a learning tool by the students at experimental group caused a significantly better understanding of concepts and knowledge related to state of matter than the students who are exposed to CMI in control group. This has indicated that students perform better and get higher marks after experiencing 7E-IIM. Thus, the null hypothesis Ho2 is rejected. The main effect of treatment was also significant which means that there was a statistically significant mean difference between groups $F(1,71)=20.66, p=0.00$. The partial $\eta^{2}$ value 0.99 indicating that $99 \%$ variance of dependent variables was explained by treatment effect, this according to Cohen (1988) as cited in Pallant [90] is a large effect size. See Table 6.4.

Table.6.4. Tests of Between-Subjects Effects Results for SMAT

\begin{tabular}{cccccc}
\hline Source & Type III SS & df & F & Sig.(p)* & Partial $\mu^{2}$ \\
\hline Treatment & 1495.29 & 1 & 20.66 & 0.00 & 0.99 \\
\hline
\end{tabular}

The finding revealed that students under 7E Inquiry Integrated Module (7E-IIM) had a higher mean score than the students under the conventional method of instruction. Therefore, the 7E-IIM has influenced student's academic achievement and retention of knowledge.

(c) Ho3. There is no significant difference in the academic achievement of students at concrete cognitive level and those at the formal cognitive level when exposed to $7 E$ Inquiry Integrated Module (7E-IIM).

To test the Ho3, the post-test SMAT scores of concrete and formal students under 7E-IIM were subjected to Mann Whitney $\mathrm{U}$ test. The summary of the analysis is presented in Table 6.5.

Table 6.5. Mann Whitney U test Analysis for SMAT Ranks of Concrete and Formal Students in Experimental Group

\begin{tabular}{cccccc}
\hline $\begin{array}{c}\text { Cognitive } \\
\text { level }\end{array}$ & N & $\begin{array}{c}\text { Mean } \\
\text { Rank }\end{array}$ & $\begin{array}{c}\text { Sum } \\
\text { of rank }\end{array}$ & U & P-value \\
\hline Concrete & 22 & 17.27 & 380.00 & 127.00 & 0.09 \\
Formal & 17 & 23.53 & 400.00 & & \\
Total & $\mathbf{3 9}$ & & & & \\
\hline
\end{tabular}


Mann Whitney $U$ test indicated that there was no statistically significant difference in academic achievement of students with respect to states of matter $\mathrm{U}$ ( concrete $=17.27$, formal $=23.53)=127.00, \mathrm{Z}=-1.71, \mathrm{P}>0.05$. It can be concluded that there is no significant difference in the post-test academic achievement of concrete and formal students in the experimental group. This shows that the 7E-IIM has positively influenced the academic achievement of both students at the formal and concrete developmental level. Though there is a mean rank difference of students at formal cognitive level, who slightly gain a higher mean score than their counterpart. The null hypothesis 3 was failed to be rejected.

Ho4. There is no significant difference in the academic achievement of students at concrete cognitive level and those at the formal cognitive level when exposed to Conventional Method of Instruction (CMI).

To test the hypothesis, the State of Matter Achievement Test scores of concrete and formal students under CMI were subjected to Mann Whitney $U$ test. The summary of the analysis is presented in Table 6.6.

Mann Whitney $U$ test indicated that there was statistically significant difference in academic achievement of students with respect to states of matter $\mathrm{U}$ ( concrete $=14.08$, formal $=21.34$ ) $=82.500, \mathrm{Z}=-2.13, \mathrm{P}<0.05$. It can be concluded that there is significant difference in the post-test academic achievement of concrete and formal students in the control group.

Table 6.6. Mann Whitney U test Analysis for SMAT Ranks of Concrete and Formal Students in Control Group

\begin{tabular}{cccccc}
\hline $\begin{array}{c}\text { Cognitive } \\
\text { level }\end{array}$ & $\mathrm{N}$ & $\begin{array}{c}\text { Mean } \\
\text { Rank }\end{array}$ & $\begin{array}{c}\text { Sum } \\
\text { of rank }\end{array}$ & U & P-value \\
\hline Concrete & 18 & 14.08 & 253.50 & 82.50 & 0.03 \\
Formal & 16 & 21.34 & 341.50 & & \\
Total & $\mathbf{3 9}$ & & & & \\
\hline
\end{tabular}

The significance difference could be as result of the ability of students at formal cognitive stage to reason in abstraction as an added advantage they had over their counterparts who operates at concrete cognitive level and may be one of the factors responsible for the observed differences between the two groups. Therefore, null hypothesis 4 which states that there is no significant difference in the academic achievement of students at concrete cognitive level and those at the formal cognitive level when exposed to Conventional Method of Instruction (CMI) is rejected. This implies that students mean scores across the groups are different. Apparently, the CMI is weak in influencing students understanding of abstract concept.

\section{Discussion of Findings}

Overall, the test of the hypothesis showed that there was a statistically significant difference in the students' academic achievement at 0.05 level of significance. This large difference in student performance may be attributed to the fact that the teacher teaching experimental group took time to elicit the student's previous experience to find out what they knew about states of matter. The result from Table 6.I, Pre-test (phase1) showed that students in both groups had the same entry behaviour in the sample, their level of performance in the SMAT score was the same, $(\mathrm{P}>0.05)$. Quantitative comparison of phase and phase2 results indicated significant positive improvement in their States of matter achievement $\mathrm{p}<0.05$. The finding revealed that student who experienced 7E Inquiry Integrated Module had higher mean score in phase2 achievement than in phase, in other words, the overall finding of the study suggested that student's academic achievement through 7E-IIM.

The significant finding indicated that the students under 7E-IIM attain success in learning States of matter than students under CMI. The attainment of success is because of practical activities and group discussion classes conducted during the intervention. Similarly, 7E inquiry integrated module had a significant effect on concrete and formal developmental level students. The researchers concluded that applying 7E-IIM for students learning in of science help to improve their academic performances regardless of their cognitive level, and this finding is in line with the findings of Mari and Gumel [97] whose study was meant to determine the effect of jigsaw on concrete and formal students' academic achievement and self-efficacy. The finding generally reveals significant improvement on the students in their academic achievement. The study, however, found a slight difference in the mean score of concrete and formal students on their chemistry achievement. Also, no significant difference was found in their self-efficacy.

A similar finding was reported by Ali, Ghazi [98] based on their study on the effectiveness of Modular Teaching in Biology at Secondary Level. Their findings reveal that modular teaching is effective. Also, Nor [99] conducted a study on the development of a Classroom Instruction Based on Constructivist 5E-learning Cycle Approach to Enhance Students' Conceptual Understanding in Data Communications and Networking. The findings reveal that the module is effective and suitable for students learning. In a related study by Alias and Siraj [100] on design and development of Physics module based on learning style and appropriate technology by Employing Isman Instructional Design Mode, the result revealed that the developed instructional module was effective in the learning outcome of students.

It is not difficult to conclude that the findings of this study support the claim that 7E-learning cycle model helps to engage students in their learning process, making them self- aware of how they learn, as well as what they learn to 
enhance overall learning experiences. This finding supports the views of [77, 101-103] who researched the effectiveness of 7E learning cycle on students' academic achievement. The finding of this study is also similar to the findings reported by Sornsakda, Suksringarm [104], indicating that students of high and low achievers attain success after undergoing 7E learning cycle.

\section{Conclusions}

Based on the present findings, the researchers believe that the following conclusions are justified.

a). Based on the empirical evidence provided in this study, the finding has shown that the 7E-Inquiry Integrated module is found to be more successful than the conventional method of instruction.

b). No matter what strategy is employed in teaching students; the success of formal developmental level students should be expected to be slightly greater than the success of concrete developmental level. That was certainly the case in this study.

c). Although the success of formal cognitive level students is likely to be greater than the performance of Concrete cognitive level students, the success of Concrete cognitive level students may be quite satisfactory if concrete concepts are studied under a carefully designed approach like 7E-Inquiry integrated module. Concrete and formal cognitive level students have statistically achieved the same results in the conceptual understanding of States of matter in the experimental group, and the possibility exists that concrete students' might performance greater than the formal developmental level based on the individual comparison. It must be stressed that this conclusion is only valid if the strategy adapted in teaching concrete does not require formal reasoning.

d). The use of the module to demonstrate the important features of formal concepts enhances the achievement of students, regardless of their intellectual level.

e). The study has confirmed the belief that well-designed teaching strategies can bridge the gap between the achievement of Concrete, and formal developmental level students, but the findings warrant further investigation of the subject matter.

f). Based on what we now know, we realise that no teaching strategy will remove the difference in achievement between Concrete, and formal-operational students, as science ideas require a formal rationale for overall understanding, and therefore more effort should be made to develop instruction that can be used to enhance the intellectual development of students.

g). The research found that both groups (experimental and control) of students reported similar scores in their States Matter Academic Test at phase3. This implies that the 7E-IIM there is no difference in retention of knowledge across the groups of students learning of States of matter. Though students under 7E-IIM slightly had a high mean score that student under Conventional Method of Instruction.

This study has a very important contribution and high implication for educational practices. This study supports the view of Hartman [105], Oyelekan and Olorundare [106], Perinpasingam and Balapumi [107], Perinpasingam, Arumugam [108] who assert that instructional module design based on effective strategy enhances academic achievement. Furthermore, research conducted by [36, 40, 46, 78-81] affirm the effectiveness of 7E learning cycle on students' academic achievement. According to Glynn, Britton [65], a student exposes to mind on activities of learning science are believed to attain success in science class. When students' readiness is established, students are motivated to learn and are more confident to ask questions from one another for a better understanding of the tasks being learnt. Findings from these studies have indicated a substantial difference between students thought under 7E learning cycle and those under conventional instruction.

\section{The Implication of the Study}

Student understanding States of the matter is very crucial in their subsequent learning of science, specifically chemistry and physics. It is suggested that since students' cognitive level is important for their understanding of science concepts. It is crucial for science teachers to identify students' cognitive development, which is to insure there should be concrete activities so that students understand abstract concepts irrespective of their level of reasoning. Since the influence of the $7 \mathrm{E}$ strategy is so strong, teachers should be encouraged to integrate this strategy into their teaching and gradually adapt it to their own personalized teaching style.

\section{Suggestions}

Based on the findings of this study, the following recommendations were made:

a). Basic science teachers should adapt mind and hands-on 7E-IIM and other various inquiry teaching strategies to enhance students' academic achievement in Basic science.

b). At the preservice level, the use and implementation of constructivist teaching strategies in the classrooms should be stressed in the methodology courses being offered by the Student-teachers at the universities and colleges of education.

c). At the in-service level, seminars and workshops should be established by ministry officials, zonal educational authority, and local education authority to 
educate practicing teachers on how to embed the 7E-IIM in schools at all levels.

d). More study to determine if there is a relationship between Lawson classroom test of Scientific reasoning (LCTSR) scores and academic achievement of children is also recommended.

\section{REFERENCES}

[1] Wennersten, R. and S. Qie, United Nations sustainable development goals for 2030 and resource use, in Handbook of Sustainability Science and Research. 2018, Springer. p. 317-339.

[2] Kirschner, P.A., J. Sweller, and R.E. Clark, Why minimal guidance during instruction does not work: An analysis of the failure of constructivist, discovery, problem-based, experiential, and inquiry-based teaching. Educational psychologist, 2006. 41(2): p. 75-86. DOI: $10.1207 / \mathrm{s} 153269$ 85ep4102_1.

[3] Ekon, E., C. Ekwueme, and A. Meremikwu, Effect of Five Phases of Constructivist Instructional Model (CIM) on Junior Secondary School Two (JSS 2) Students' Cognitive Achievement and Interest in Basic Science and Mathematics in Cross River State of Nigeria. Journal of Education, 2014. 4(3): p. 74-77.

[4] Ayodele, M.O., Attitude, Self-Concept and Achievement of Junior Secondary School Students in Basic Science in Ekiti State, Nigeria. Journal of Educational and Social Research, 2016. 6(1): p. 167.

[5] Buba, M.A. and S.T. Kojigili, Content Validation of Basic Education Certificate Examination Questions in Basic Science in Adamawa State, Nigeria. Journal of Education, Society and Behavioural Science, 2020: p. 42-54. DOI: 10.9734/JESBS/2020/v33i230201.

[6] Samuel, I., Assessment of basic science teachers' pedagogical practice and students' achievement in Keffi Educational Zone, Nasarawa State, Nigeria. An Unpublished Masters Dissertation, Nasarawa State University, Keffi, Nigeria, 2017.

[7] Karpudewan, M., A.N.M. Zain, and A. Chandrasegaran, Introduction: Misconceptions in science education: An overview, in Overcoming Students' Misconceptions in Science. 2017, Springer. p. 1-5.

[8] Nguru, F., Children's learning about matter and its change of state: A learning study approach. 2018, The University of Dodoma.URI: http://hdl.handle.net/20.500.12661/1701.

[9] Özalp, D. and A. Kahveci, Diagnostic assessment of student misconceptions about the particulate nature of matter from ontological perspective. Chemistry Education Research and Practice, 2015. 16(3): p. 619-639.

[10] Harrison, A.G. and D.F. Treagust, The particulate nature of matter: Challenges in understanding the submicroscopic world, in Chemical education: Towards research-based practice. 2002, Springer. p. 189-212.

[11] Othman, J., D.F. Treagust, and A. Chandrasegaran, An investigation into the relationship between students' conceptions of the particulate nature of matter and their understanding of chemical bonding. International Journal of Science Education, 2008. 30(11): p. 1531-1550.

[12] Tatar, E., Prospective primary school teachers misconceptions about states of matter. Educational Research and Reviews, 2011. 6(2): p. 197-200. http://www.academicjournals.org/ERR.

[13] Treagust, D.F., et al., Evaluating students' understanding of kinetic particle theory concepts relating to the states of matter, changes of state and diffusion: A cross-national study. International Journal of Science and Mathematics Education, 2010. 8(1): p. 141-164. doi:10.1007/s10763-009 -9166-y.

[14] Odia, L. and S. Omofonmwan, Educational system in Nigeria problems and prospects. Journal of social sciences, 2007. 14(1): p. 86-85.

[15] Ogunmade, T.O., The status and quality of secondary science teaching and learning in Lagos State, Nigeria. 2005.

[16] Okedeyi, A.S., et al., Nigerian Science Teachers' Perceptions of Effective Science Teaching and their Classroom Teaching Practices in Junior Secondary Schools in Lagos State, Nigeria. Journal of Education and Practice, 2013. 4(25): p. 8.

[17] Osuolale, O.J., Problems of teaching and learning science in junior secondary schools in Nasarawa State, Nigeria. Journal of Education and Practice, 2014. 5(34): p. 109-118.

[18] Knowles, M. and E. Holton III, III; Swanson, RA. The adult learner: The definitive classic in adult education and human resource development, 6th ed. Burlington, MA: Elsevier, 2005.

[19] Cheng, M.M., Students' visualisation of chemical reactions-insights into the particle model and the atomic model. Chemistry Education Research and Practice, 2018. 19(1): p. 227-239.

[20] Doymus, K., Effects of a cooperative learning strategy on teaching and learning phases of matter and one-component phase diagrams. Journal of Chemical Education, 2007. 84(11): p. 1857.

[21] Laliyo, L.A.R., et al., Analytic Approach Of Response Pattern Of Diagnostic Test Items In Evaluating Students' Conceptual Understanding Of Characteristics Of Particle Of Matter. Journal of Baltic Science Education, 2020. 19(5): p. 824.

[22] Lee, O., et al., Changing middle school students' conceptions of matter and molecules. Journal of Research in Science Teaching, 1993. 30(3): p. 249-270.

[23] Rahayu, S. and M. Kita, an Analysis of Indonesian And Japanese Students' understandings Of Macroscopic And Submicroscopic Levels of Representing Matter and Its Changes. International Journal of Science and Mathematics Education, 2010. 8(4): p. 667-688.

[24] Treagust, D.F., et al., Evaluation of an intervention instructional program to facilitate understanding of basic particle concepts among students enrolled in several levels of study. Chemistry Education Research and Practice, 2011. 12(2): p. 251-261. 
[25] Yezierski, E.J. and J.P. Birk, Misconceptions about the particulate nature of matter. Using animations to close the gender gap. Journal of Chemical Education, 2006. 83(6): p. 954.

[26] Boo, H.K., \& Watson, J. R, Progression in high school students'(aged 16-18) conceptualizations about chemical reactions in solution. Science education, 2001. 85(5): p. 568-585.

[27] Sunar, S., The effect of context-based instruction integrated with learning cycle model on students' achievement and retention related to states of matter subject. Unpublished doctoral dissertation). Middle East Technical University, Ankara, 2013.

[28] Cantu, L.L. and J.D. Herron, Concrete and formal Piagetian stages and science concept attainment. Journal of Research in Science Teaching, 1978. 15(2): p. 135-143.

[29] Kind, V., Beyond appearances: Students’ misconceptions about basic chemical ideas. 2004, London: Royal Society of Chemistry.

[30] Tsitsipis, G., D. Stamovlasis, and G. Papageorgiou, The effect of three cognitive variables on students' understanding of the particulate nature of matter and its changes of state. International Journal of Science Education, 2010. 32(8): p. 987-1016. DOI: 10.1080/095006909028936 05

[31] Pozo, J.I. and M.A. Gomez Crespo, The embodied nature of implicit theories: The consistency of ideas about the nature of matter. Cognition and instruction, 2005. 23(3): p. 351-387. DOI: 10.1207/s1532690xci2303_2.

[32] Talanquer, V., On cognitive constraints and learning progressions: The case of "structure of matter". International Journal of Science Education, 2009. 31(15): p. 2123-2136. DOI: 10.1080/09500690802578025.

[33] Pereira, M.P., and Maria Elisa M. Pestana, "Pupils' representations of models of water.". International Journal of Science Education 1991.3(13).URL:https://doi.org/10.10 80/0950069910130309.

[34] Adak, S., Effectiveness of Constructivist Approach on Academic Achievement in Science at Secondary Level. Educational Research and Reviews, 2017. 12(22): p.1074-1079.DOI: 10.5897/ERR2017.3298.

[35] Adesoji, F.A. and M.I. Idika, Effects of 7E Learning Cycle Model and Case-Based Learning Strategy on Secondary School Students' Learning Outcomes in Chemistry. Journal of the International Society for Teacher Education, 2015. 19(1): p. 7-17.

[36] Çekiç Toroslu, S., Effect of 7E learning model integrated with real-life context based instruction on students' conceptual achievement, misconceptions and science process skills about “energy". Unpublished PhD thesis, Gazi University, Ankara, Turkey, 2011.

[37] Bozorgpouri, M., The Study Of Effectiveness of Seven-Step (7E) Teaching Method In The Progress Of English Learning In Students Shiraz City. 2016.

[38] Celik, H., G. Özbek, and T. Kartal, The Effect of the computer-aided 7E teaching model on students' science process skills. Mediterranean Journal of Educational
Research, 2013.

[39] Gürbüz, F., Ü. Turgut, and R. Salar, The Effect of 7E Learning Model on Academic Achievements and Retention of 6th Grade Science and Technology Course Students in the Unit" Electricity in Our Life". Journal of Turkish Science Education, 2013. 10(3).

[40] Gurbuz, F., The effect 7e model on academic achievement and retention of knowledge in the unit of "Electricity in our Life" in 6th grade science and technology (Unpublished doctoral thesis). Ataturk University, Turkey, 2012.

[41] Wijayanti, Y., H. Hartono, and I. Rachman, Effect of Learning Cycle 7E towards Science Process Skills of Eleventh Science graders in State Senior high School 4 in Palembang. 2014.

[42] Naade, N., J. Alamina, and P. Okwelle, Effect of 7E's's Constructivist Approach on Students' Achievement in Electromagnetic Induction Topic in Senior Secondary School in Nigeria. Journal of Education, Society and Behavioural Science, 2018: p. 1-9. DOI: 10.9734/JESBS/20 18/39997.

[43] Alamina, J.I. and I.S. Etokeren, Effectiveness of Imagination Stretch Teaching Strategy in Correcting Misconceptions of Students about Particulate Nature of Matter. Journal of Education, Society and Behavioural Science, 2018: p. 1-11.

[44] Qarareh, A.O., The effect of using the learning cycle method in teaching science on the educational achievement of the sixth graders. International Journal of Educational Sciences, 2012. 4(2): p. 123-132.

[45] Soomro, A.Q., et al., Teaching Physics through Learning Cycle Model: An Experimental Study. Journal of Educational Research (1027-9776), 2010. 13(2).

[46] Turgut, U., A. Colak, and R. Salar, How is the learning environment in physics lesson with using 7E model teaching activities. European Journal of Education Studies, 2017.

[47] Eisenkraft, A., A proposed 7E model emphasizes 'transfer of learning' and the importance of eliciting prior una'erstanding. The Science Teacher, 2003. 70: p. 6.

[48] Adewale, J. and S. Awolola, Impact of brain-based instructional strategy on students' attitude to senior secondary school mathematics in Oyo State, Nigeria. 2011.

[49] Aina, J.K. and K. Langenhoven, Teaching method in science education: the need for a paradigm shift to peer instruction (PI) in Nigerian schools. International Journal of Academic Research and Reflection, 2015. 3(6): p. 6-15.

[50] Awofala, A.O., An Analysis of the New 9-Year Basic Education Mathematics Curriculum in Nigeria. Acta Didactica Napocensia, 2012. 5(1): p. 17-28.

[51] Bukunola, B.-A.J. and O.D. Idowu, Effectiveness of cooperative learning strategies on Nigerian junior secondary students' academic achievement in basic science. Journal of Education, Society and Behavioural Science, 2012: p. 307-325.

[52] Damola, O., A. Adebimbo, and S.O. Alaba, Enhancing Students' Performance in Basic Science and Technology in Nigeria Using Moodle LMS. World Academy of Science, 
Engineering and Technology, International Journal of Social, Behavioral, Educational, Economic, Business and Industrial Engineering, 2016. 10(5): p. 1657-1660.

[53] Danjuma, G., Effects of collaborative and competitive learning strategies on upper Basic II learners' interest and achievement in Basic Science Unpublished Ph. D Thesis, 2015.

[54] Etukudo, D.U., Factors affecting teaching and learning of basic science and technology in primary schools. Journal of educational policy and entrepreneurial research, 2014. 1(1): p. 46-58.

[55] Kabutu, F.R., O.I. Oloyede, and M.F. Ogunsola-Bandele, An Investigation into The Achievement of Junior Secondary School Students Taught Integrated Science Using the Cooperative Learning Strategy in Nigeria. Eurasian Journal of Physics \& Chemistry Education, 2015. $7(2)$.

[56] Ndirika, M., Achievement Variations of Basic Science Students Taught with Teacher-Centred, Teacher/Student-Centered and Student-Centered Instructions in Kaduna State, Nigeria. Journal of Educational and Social Research, 2012. 2(8): p. 24-33.

[57] Nneji, L., Impact Of Framing And Team Assisted Individualized Instructional Strategies Students' Achievement In Basic Science In The North Central Zone Of Nigeria. Knowledge Review, 2011. 23(4): p. 1-8.

[58] Obomanu, B. and J. Akporehwe, The Effect of Home Related Science Activities on Students' Performance in Basic Science. World Journal of Education, 2012. 2(1): p. 131-136. doi:10.5430/wje.v2n1p131.

[59] Omorogbe, E. and J.C. Ewansiha, The challenge of effective science teaching in Nigerian secondary schools. Academic Journal of Interdisciplinary Studies, 2013. 2(7): p. 181.

[60] Wadsworth, B.J., Piaget's theory of cognitive and affective development: Foundations of constructivism. 1996: Longman Publishing.

[61] Augustinah, N.D. and A.O. Bolajoko, Effects of constructivists' learning strategies on senior secondary school students achievement and retention in biology. Mediterranean Journal of Social Sciences, 2014. 5(27 P2): p. 627-627.

[62] Bada, S.O. and S. Olusegun, Constructivism learning theory: A paradigm for teaching and learning. Journal of Research \& Method in Education, 2015. 5(6): p. 66-70.

[63] Bimbola, O. and O.I. Daniel, Effect of constructivist-based teaching strategy on academic performance of students in integrated science at the junior secondary school level. Educational Research and Reviews, 2010. 5(7): p. 347.

[64] Richardson, V., Constructivist pedagogy. Teachers college record, 2003. 105(9): p. 1623-1640.

[65] Glynn, S.M., B.K. Britton, and R.H. Yeany, The psychology of learning science. 2012: Routledge.

[66] Moreno, R., Decreasing cognitive load for novice students: Effects of explanatory versus corrective feedback in discovery-based multimedia. Instructional science, 2004. 32(1-2): p. 99-113.
[67] Cakici, Y. and G. Yavuz. The effect of constructivist science teaching on 4th grade students' understanding of matter. in Asia-Pacific Forum on Science Learning and Teaching. 2010. The Education University of Hong Kong, Department of Science and....

[68] Yilmaz, K., The cognitive perspective on learning: Its theoretical underpinnings and implications for classroom practices. The Clearing House: A Journal of Educational Strategies, Issues and Ideas, 2011 84(5): p. 8.

[69] Aulls, M.W., The contributions of co-occurring forms of classroom discourse and academic activities to curriculum events and instruction. Journal of educational psychology, 2002. 94(3): p. 520

[70] Oluremi, O.F. and B.K. Oyewole, Supervision for quality assurance in universal basic education programme in Nigeria. Mediterranean Journal of Social Sciences, 2013. 4(6): p. 447.

[71] Wasagu, M.A. Rethinking science education for the changing times: The writing on the wall. 2009. Central Coordinating Committee for University Inaugural Lectures and Seminars.

[72] Balta, N. and H. Sarac, The Effect of 7E Learning Cycle on Learning in Science Teaching: A Meta-Analysis Study. European Journal of Educational Research, 2016. 5(2): p. 61-72.

[73] Jati, N. and I. Slamet. Students' Mathematical Communication Ability using Learning Cycle 7E on Junior High School. in Journal of Physics: Conference Series. 2017. IOP Publishing.

[74] Bybee, J., Cognitive processes in grammaticalization. The new psychology of language, 2014. 2: p. 145-167.

[75] Lamanna, S.M., Inquiry-Based Learning and Student Retention, in Department of Education and Human Development. 2010, State University of New York College at Brockport

[76] Bybee, R.W., et al., The BSCS 5E instructional model: Origins and effectiveness. Colorado Springs, Co: BSCS, 2006. 5: p. 88-98.

[77] Gök, G., The effect of 7E learning cycle instruction on 6th grade students' conceptual understanding of human body systems, self-regulation, scientific epistemological beliefs, and science process skills. Unpublished doctoral dissertation). Middle East Technical University, Ankara, Turkey, 2014.

[78] Kanli, U. and R. Yagbasan, The Effect of Laboratory Based on The 7E Learning Cycle Model And Verification Laboratory Approach On The Development Of Students' Science Process Skill and Conceptual Achievement. Essays in education, special edition, hal, 2007: p. 143-153.

[79] Mecit, Ö., The effect of 7E learning cycle model on the improvement of fifth grade students' critical thinking skills. 2006.

[80] Vick, V.C., The Effect Of 7E Model Inquiry-Based Labs on Student Achievement In Advanced Placement Physics: An Action Research Study. 2018.. Retrieved. from. https://scho larcommons.sc.edu/etd/4580.

[81] Yenice, E., The effect of 7e model of the constructivist 
approach to the success of students' about meiosis and mitosis division and permanence of their knowledge. 2014, Master Thesis). The central thesis of Higher Education Institutions.(354519).

[82] Sarac, H., The Effect of Learning Cycle Models on Achievement of Students: A Meta-Analysis Study. International Journal of Educational Methodology, 2018. 4(1): p. $1-18$

[83] Sarac, H. and D. Tarhan, Effect of Multimedia Assisted 7e Learning Model Applications on Academic Achievement and Retention in Students. European Journal of Educational Research, 2017. 6(3): p. 299-311.

[84] Bell, R.L., L. Smetana, and I. Binns, Simplifying inquiry instruction. The Science Teacher, 2005. 72(7): p. 30-33.

[85] Martin-Hansen, L., Defining inquiry. The science teacher, 2002. 69(2): p. 34.

[86] Turgut, U., A. Colak, and R. Salar, The Effect of 7E Model on Conceptual Success of Students in the Unit of Electromagnetism. European Journal of Physics Education, 2016. 7(3): p. 1-37.

[87] Gürbüz, F., The effect of 7e learning model on academic achievements and retention of students in the unit of "electricity in our life" 6th grade science and technology course. Unpublished doctoral dissertation). Ataturk University, Erzurum, Turkey, 2012.

[88] Ndihokubwayo, R. Innovative graphic presentation of theoretical and conceptual frameworks (TF \& CF): an option to explore in the built environment research education. in 11th ICEBE \& 7TH ICIE \& PEESA III International Conference on Engineering and Business Education, Innovation and Entrepreneurship, and Capacity Building in Higher Education. 2018. Poland.

[89] Özmen, H., Some student misconceptions in chemistry: A literature review of chemical bonding. Journal of Science Education and Technology, 2004. 13(2): p. 147-159.

[90] Woolfolk Hoy, A., H.A. Davis, and E.M. Anderman, Theories of learning and teaching in TIP. Theory into practice, 2013. 52(sup1): p. 9-21.

[91] Thompson, I., The mediation of learning in the zone of proximal development through a co-constructed writing activity. Research in the Teaching of English, 2013: p. 247-276.

[92] Jackaria, P.M., A. Buan, and C. Yuenyong. Students' Performance in Context-Based Lessons in Mathematics Classroom. in Journal of Physics: Conference Series. 2019. IOP Publishing.

[93] Han, J., Scientific reasoning: Research, development, and assessment. 2013, The Ohio State University.

[94] Korb, K.A., Conducting educational research. Retrieved May, 2012. 11: p. 2012.

[95] Wells, C.S. and J.A. Wollack, An instructor's guide to understanding test reliability. Testing \& Evaluation Services. University of Wisconsin, 2003.

[96] Gongden, E.J., D. John, and E. Gimba, Effects of jigsaw cooperative learning strategy on senior secondary two chemistry students' understanding of chemical kinetics in
Jos South LGA of Plateau state, Nigeria. East African Scholars Journal of Education, Humanities and Literature, 2 (5), 2019: p. 280-288.

[97] Mari, J. and S.A. Gumel, Effects of jigsaw model of cooperative learning on self-efficacy and achievement in chemistry among concrete and formal reasoners in colleges of education in Nigeria. International Journal of Information and Education Technology, 2015. 5(3): p. 196.

[98] Ali, R., et al., Effectiveness of modular teaching in biology at secondary level. Asian Social Science, 2010. 6(9): p. 49.

[99] Nor, N.M., Development of a Classroom Instruction Based on Constructivist 5E-learning Cycle Approach to Enhance Students' Conceptual Understanding in Data Communications and Networking. 2014, Universiti Teknologi Malaysia.

[100] Alias, N. and S. Siraj, Design and Development of Physics Module Based on Learning Style and Appropriate Technology by Employing Isman Instructional Design Model. Turkish Online Journal of Educational Technology-TOJET, 2012. 11(4): p. 84-93.

[101] Abdi, A., The Effect of Inquiry-Based Learning Method on Students' Academic Achievement in Science Course. Universal journal of educational Research, 2014. 2(1): p. 37-41.

[102] Khashan, K., The Effectiveness of Using the 7E's Learning Cycle Strategy on the Immediate and Delayed Mathematics Achievement and the Longitudinal Impact of Learning among Preparatory Year Students at King Saud University (KSU). Journal of Education and Practice, 2016. 7(36): p. 4052. URL:https://files.eric.ed.gov/fulltext/EJ112 6536.pdf.

[103] Rahmy, S.N., B. Usodo, and I. Slamet. Students' mathematics learning achievement in junior high school using 7E learning cycle. in Journal of Physics: Conference Series. 2019. IOP Publishing.

[104] Sornsakda, S., P. Suksringarm, and A. Singseewo, Effects of Learning Environmental Education Using the 7E-Learning Cycle with Metacognitive Technique and Teachers Handbook Approaches on Learning Achievement, Integrated Science Process Skills and Critical Thinking of Mathayomsuksa 5 Students with Different Learning Achievement. Pakistan Journal of Social Sciences, 2009. 6(5): p. 297-303.

[105] Hartman, S.A., Development of" Teachers Integrating Physical Activity into the Curriculum"(TIPAC) Using a Systems Model Approach. 2017, University of Akron.

[106] Oyelekan, O. and A. Olorundare, Development and validation of a computer instructional package on electrochemistry for secondary schools in Nigeria. International Journal of Education and Development using ICT, 2009. 5(2): p. 88-104.

[107] Perinpasingam, P.T.S. and R. Balapumi, Designing and evaluating a web-based lesson for English language instruction. The English teacher, 2017: p. 22. URL: http://dx.doi.org/10.5539/res.v6n3p31.

[108] Perinpasingam, P.T.S., et al., Development of a Science module through Interactive Whiteboard. Rev. Eur. Stud., 2014. 6: p. 31. 